\title{
COL3A1 Gene
}

National Cancer Institute

\section{Source}

National Cancer Institute. COL3A1 Gene. NCI Thesaurus. Code C143052.

This gene plays a role in collagen formation in connective tissues. 